SFB

Reforming the EU emissions trading system: An alternative to the market stability reserve

823

Mark A. Andor, Manuel Frondel,

Stephan Sommer

Nr. 19/2015

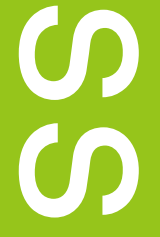

(

0

(1)

SFB
823 



\title{
Reforming the EU Emissions Trading System: An Alternative to the Market Stability Reserve
}

\author{
Mark A. Andor ${ }^{\mathrm{a}}$, Manuel Frondel ${ }^{\mathrm{b}}$ and Stephan Sommer ${ }^{\mathrm{a}}$
}

\begin{abstract}
Prices for emission allowances in Europe’s Emissions Trading System (ETS) have remained low for many years. This fact has given rise to controversies on whether there is a need for a fundamental reform of the ETS. Potential reform proposals include the introduction of a price floor for certificates and a market stability reserve (MSR), which is a rule-based mechanism to steering the market volume of allowances and the preferred approach of the European Commission. With the introduction of the MRS, the Commission aims at increasing and stabilizing certificate prices in the medium- and long-term. In this article, we alternatively recommend retaining the ETS as it is, rather than supplementing it by introducing a minimum price floor or a market stability reserve. Instead, mistakes from the past should be corrected by a single intervention: the final elimination of those 900 million allowances that were taken out of the market in 2014, but would again emerge in the market in 2019 and 2020 via backloading.
\end{abstract}

JEL Code: Q50, Q58

Keywords: emissions tax, emissions cap, price corridor.

Contact Person: Manuel Frondel, Rheinisch-Westfälisches Institut für Wirtschaftsforschung (RWI), Hohenzollernstr. 1-3, 45128 Essen, frondel@rwi-essen.de.

Acknowledgement: We thank Christoph M. Schmidt and Colin Vance for valuable suggestions and the Federal Ministry of Education and Research (BMBF) for financial support under grant 01LA1113A. This work has also been partly supported by the Collaborative Research Center "Statistical Modeling of Nonlinear Dynamic Processes" (SFB 823) of the German Research Foundation (DFG), within the framework of Project A3, "Dynamic Technology Modeling".

\footnotetext{
${ }^{a}$ Rheinisch-Westfälisches Institut für Wirtschaftsforschung

${ }^{\mathrm{b}}$ Rheinisch-Westfälisches Institut für Wirtschaftsforschung and Ruhr-Universität Bochum
} 


\section{Introduction}

The global number of emissions trading systems steadily increases. Ten years after launching the emissions trading scheme in the European Union (EU) in 2005, the International Carbon Action Partnership (ICAP, 2015) currently counts 17 such systems on four continents. ${ }^{1}$ These regions account for $40 \%$ of the global Gross Domestic Product (GDP). Just recently, at the beginning of 2015, South Korea implemented a nation-wide ETS, while China foresees the introduction of a nation-wide system for 2016.

The European Emissions Trading System (ETS) is the central instrument to reduce Greenhouse Gas (GHG) emissions in Europe. About 45\% of the EU-wide GHG emissions are covered by this scheme (EC, 2013). With the help of the ETS, the European Commission aims at reducing carbon dioxide $\left(\mathrm{CO}_{2}\right)$ emissions by $20 \%$ until 2020 and by $30 \%$ until 2030 relative to the 1990 level. To this end, the EU-wide maximum of emissions covered by the ETS, the so-called cap, is annually reduced by 1.74\% between 2013 and 2020 (EP, 2010); from 2021 onwards the cap shall be decreased by 2.2\% per year (CEU, 2014).

Compared to the price peak of about $30 €$ that was reached in April 2006, allowance prices have remained low for years, ranging between 3 and $9 €$ in the period from January 2012 to January 2015 (Figure 1). This fact sparked controversial discussions about this climate protection instrument. Some argue that the design of the ETS is not effective in mitigating climate change when allowance prices are low, and therefore needs reforming. These low prices are the consequence of large amounts of excess allowances. In fact, the number of excess allowances amounted to two billion at the beginning of the third trading phase in 2013 (EC, 2015). This surplus arose from the large difference between allocated allowances (supply) and verified emissions (demand). Hence, in 2014 the European Commission (EC, 2014a) resolved to intervene into the operation of the ETS and postponed the auction of 900 Million allowances from 2014-2016 to 2019 and 2020, a process referred to as backloading.

Since this intervention only temporarily limits the supply of allowances, but does not solve the structural problem of both excess allowances and low prices, the European Commission recently decided to introduce a so-called market stability reserve (MRS), with its

\footnotetext{
${ }^{1}$ Apart from the European Emissions Trading System, there are 16 trading schemes that are implemented in the following countries: Canada (Québec Cap-and-Trade System), China (Beijing, Chongqing, Guandong, Hubei, Shanghai, Shenzhen and Tianj), Japan (Saitama Target Setting Emissions Trading System and Tokyo Cap-andTrade Program), Kazakhstan (KAZ ETS), Korea (Korea Trading Scheme), New Zealand (NZ ETS), Switzerland (Swiss ETS), USA (California Cap-and-Trade Program and RGGI) (ICAP, 2015).
} 
introduction being foreseen for 2019. The core of the MRS is a rule-based mechanism that automatically steers the amount of circulating allowances by withdrawing and storing them in a reserve when the number of excess allowances exceeds an upper limit. Conversely, allowances are returned to the market when the number of excess allowances falls below a lower limit. With the help of the MSR, the Commission hopes to stabilize allowance prices on a higher level than currently observed.

Figure 1: Allowance Prices in the European Emissions Trading System (January 2012-January 2015)

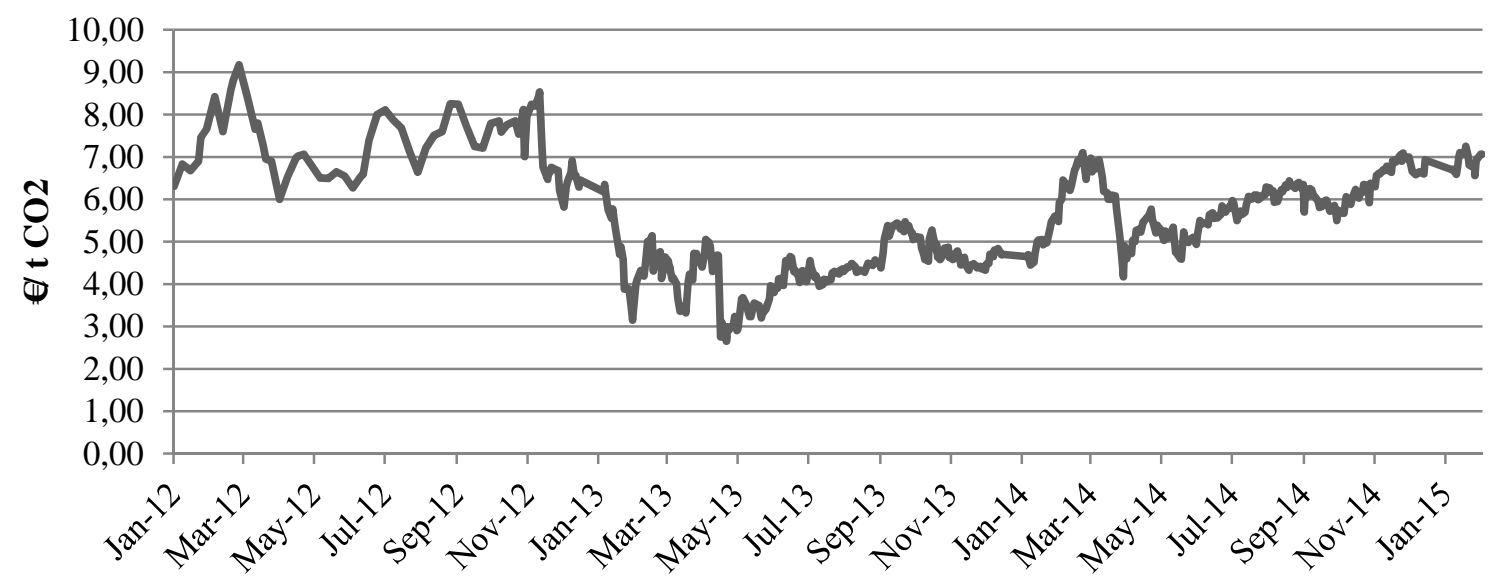

Source: EEX (2015)

Alternative reform proposals include the implementation of price floors, which is supported by the German Advisory Council on the Environment (SRU, 2011:255), and a price corridor for allowances (Fell and Morgenstern, 2010; Wood and Jotzo, 2011). Specifically, limiting the price volatility at the lower end is expected to lead to a minimum level of security for investments in abatement technologies (acatech et al., 2015:19; Grüll and Taschini, 2011).

Based on a theoretical discussion on the relative merits of alternative reform proposals, this article recommends retaining the ETS as it is, rather than supplementing it by introducing a minimum price floor or a market stability reserve. With respect to the market stability reserve, we argue that this instrument is not sufficient to increase allowance prices markedly in the short run. Although price floors and corridors are frequently asserted to be more effective alternatives, we demonstrate why the implementation of these instruments is not desirable either.

In the subsequent section, we describe the basic principles of the ETS, as well as the key reasons for the large number of excess allowances, which ultimately led to the controversial debate about this climate protection instrument. Section 3 presents the concept of the market stability reserve and the design proposed by the Commission to tackle the huge 
surplus of allowances. Section 4 theoretically discusses whether price- or quantity-based instruments are preferable when there is incomplete information and decisions must be made under uncertainty - as it is inevitably the case in reality. The final section suggests an alternative reform of the ETS.

\section{Reasons for the Surplus of Allowances}

According to economic theory, certificate trading is a cost-efficient instrument to achieve a fixed environmental target in the short run (Baumol and Oates, 1988; Bonus, 1998). Among other reasons, this is why the Commission established the ETS as a central instrument to impel climate protection in Europe. Along with the primary target of reducing GHG emissions cost-efficiently, by means of pricing emissions, the ETS is supposed to provide incentives to invest in low-carbon technologies.

Holding allowances entitles those companies covered by the ETS to emit the respective number of tons of $\mathrm{CO}_{2}$ or its equivalent of other greenhouse gases. ${ }^{2}$ In the meantime, there is a liquid trade in allowances at the stock market, so that it is warranted to regard stock prices as the reference price for bilateral trades. At the end of each year, participating companies have to hold at least that amount of allowances that equals its actual emissions; otherwise, fines are imposed. In 2013, the fine for each lacking certificate amounted to $100 €$, but this level is adjusted yearly, taking the inflation rate into account (EC, 2013). The fine does not absolve from the obligation to purchase the remaining allowances. Since these have to be procured despite settling the fine, the fine does not imply an upper price limit for allowances, as is sometimes erroneously claimed.

Companies base their climate protection effort on the market price for allowances: if the price exceeds their individual marginal abatement costs, companies will invest in technologies with lower emissions. Conversely, if the allowance price is below their marginal abatement costs, companies will forego investments in more efficient technologies and instead purchase allowances. In the past years, the allowance price ranged between 6 and $9 €$. This relatively low price is mainly attributed to a huge surplus of allowances in the market. A surplus emerges if the cumulated number of allowances exceeds the (verified) actual emissions.

\footnotetext{
${ }^{2}$ In the following, although solely speaking of $\mathrm{CO}_{2}$ for brevity, we, in fact, refer to $\mathrm{CO}_{2}$-equivalents, as along with $\mathrm{CO}_{2}$, the ETS comprises Nitrous Oxide $\left(\mathrm{N}_{2} \mathrm{O}\right)$ and Perfluorocarbons (PFC).
} 
There are manifold reasons for the huge surplus of excess allowances: One reason is the unexpected low emission level as a consequence of the longstanding and severe economic crisis that erupted in 2008. Most notably, Southern European countries have been strongly afflicted by the crisis and have not yet recovered economically. Another reason is the generation of green electricity in Europe. Both the Commission and individual Member States defined targets for the shares of green electricity in consumption and established promotion schemes that overlap with the ETS. In Germany, for instance, the generation of $\mathrm{CO}_{2}$-free electricity, which is promoted by fixed feed-in-tariffs for renewable energy sources (RES), leads to a decreased demand for emission allowances in the German power sector (characterized in Figure 2 by a shift of the demand curve from $D_{0}$ to $D_{1}$ ).

Consequently, the allowance price drops from $p_{0}$ to $p_{1}$, so that market participants of other sectors and countries can purchase allowances at lower prices. For instance, in their empirical analysis, Koch et al. (2014:681) find certificate price elasticity estimates of wind and solar electricity production falling between -0.11 and -0.15 . As a result, more $\mathrm{CO}_{2}$ will be emitted outside the German power sector than without promoting RES in Germany, as companies refrain from investing in abatement technologies due to reduced allowance prices. In effect, owing to the coexistence with the ETS, the promotion of RES does not reduce emissions, but rather leads to a shift in emissions within the EU (BMWA, 2004). The same argument holds for other abatement measures that affect the sectors covered by the ETS, such as energy efficiency policies and the national $\mathrm{CO}_{2}$ tax in the United Kingdom.

Admittedly, the Commission was quite successful in anticipating the emissionsreducing effect of green electricity promotion and in taking it into account for setting the emissions cap for 2020. The massive deployment of RES in some countries, however, particularly in Germany (Frondel et al., 2015), could not have been foreseen. In the end, the total amount of green electricity produced in the EU exceeded the amount that entered the calculations for the emissions cap - causing downward pressure on allowance prices (Agora Energiewende, 2015). 


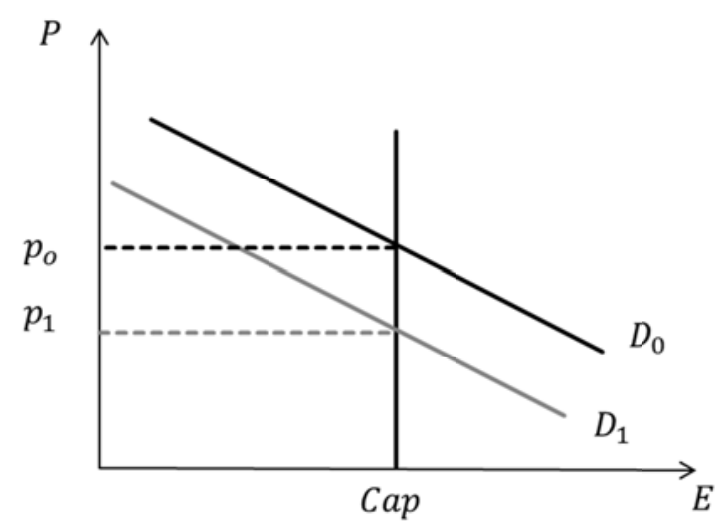

A downward pressure on prices also results from offsets that are issued for international climate projects. Within the Kyoto Protocol, it is explicitly allowed that offsets from the so-called Clean-Development Mechanism (CDM) and Joint-Implementation (JI) measures can be used in the ETS. By means of implementing and financing CDM measures in developing countries, such as electrification projects with solar panels, companies receive offsets (Certified Emission Reductions, CERs). Furthermore, offsets from JI measures (Emission Reduction Units, ERUs) are granted for companies that conduct emission reducing projects in other countries that signed the Kyoto Protocol. These offsets are both equivalent to the right to emitting one ton of GHG emissions in the EU.

CDM measures aim at stimulating growth in developing countries and help developed countries to achieve their emission targets in a more flexible and cost-effective way. After all, for the global climate it is irrelevant whether emissions are avoided in- or outside the EU. Likewise, JI measures offer a flexible and cost-efficient possibility to reduce emissions for the implementing companies, whilst partner countries benefit from foreign investments, as well as the transfer of technology and knowledge. By now, about 7,600 CDM projects have been registered and 1.5 billion CERs have been issued. In addition, about 872 million ERUs have been granted for JI measures (UNFCCC, 2015a; b).

The huge number of such offsets is deemed to be mainly responsible for the surplus of allowances in the ETS (SRU, 2011:249; Öko-Institut, 2013). As a consequence of the excess supply of such offsets, and the fact that dubious projects were supported, regulations were tightened at the beginning of the third trading phase in 2013. Actually, the number of ERUs and CERs to be employed in the ETS was limited to half of the emissions to be reduced 
between 2008 and 2020; this is equivalent to 1.6 billion allowances. $^{3}$ Since 2013, neither reforestation projects, nor the combustion of Perfluorocarbons (PFC) and the destruction of Nitrous oxide $\left(\mathrm{N}_{2} \mathrm{O}\right)$ are remunerated through ERUs anymore. ${ }^{4}$

Yet, the offsets resulting from already approved projects can still be used in the ETS, because it is allowed to transfer excess allowances from the second to the third trading phase (banking). Therefore, the Öko-Institut (2013), as well as Neuhoff and Schopp (2013), ascribe the major part of the two billion excess allowances observed at the beginning of the third trading phase to the huge number of available CERs and ERUs. According to the Öko-Institut (2013), these offsets are responsible for 1.5 billion excess allowances; the remaining surplus may be attributed to the aftermath of the economic crisis in the late 2010s.

\section{The Market Stability Reserve (MSR)}

According to critics, the massive surplus of allowances and the resulting lack of scarcity signals do not lead to sufficient investments in carbon-extensive technologies. To spur investment incentives, several reform proposals have been suggested, among others the introduction of a market stability reserve (EC, 2014b), on which the EU institutions (Commission, Council, and Parliament) are expected to decide upon in 2015. This rule-based mechanism automatically steers the annual amount of allowances to be auctioned.

With the MSR, the Commission pursues two main objectives: first, reducing the high amount of excess allowances in the short term and, second, stabilizing allowance prices in the long term. To this end, an independent institution is supposed to determine the accumulated amount of allowances once a year. If at the end of year $t$ the number of allowances exceeds the upper limit (833 million according to the EC proposal), the volume of auctioned allowances will be reduced by $12 \%$, but at least by 100 million, in January of year $t+2$ and will be transferred to the reserve (Figure 3). Thus, this mechanism could prove effective only with a time lag of up to one year. ${ }^{5}$ If, on the other hand, the accumulated surplus is below the

\footnotetext{
${ }^{3}$ According to the EU Linking Directive, Germany may use up to $22 \%$ of the allowances resulting from international projects. Thus, during the third trading phase, German operators can acquire about 450 million offsets arising from realizing CDM and JI measures.

${ }^{4}$ The major part (58\%) of the CERs used in the ETS originates from PFC projects (abatement costs: about 50 $\mathrm{ct} / \mathrm{t} \mathrm{CO}_{2}$ ), while another $24 \%$ originates from similar $\mathrm{N}_{2} \mathrm{O}$ projects (abatement costs about $1 \mathrm{EUR} / \mathrm{t} \mathrm{CO}_{2}$ ) (Agora Energiewende, 2015). The climatic impact of both PFC and $\mathrm{N}_{2} \mathrm{O}$ is by far much higher than that of $\mathrm{CO}_{2}$, but they can be destructed at very low costs. While this procedure is legally prescribed in developed countries, the destruction was realized in CDM measures in China, India, South Korea and Mexico, to name but a few developing countries. Therefore, the resulting, inexpensive allowances are controversially discussed.

${ }^{5}$ Actually, the time lag is shorter, because the verified emissions would be published in May of year $t+1$ (Gibis et al., 2015:29).
} 
lower limit (400 million according to the EC proposal), an additional amount of 100 million allowances will be taken from the reserve and additionally auctioned at the market (DEHSt, 2014).

Given the time lag of up to one year and the fact that, according to the proposal of the Commission, the MSR shall be introduced only in 2019, the surplus of allowances will be reduced only gradually by this instrument. In fact, the contrary might be the case for the upcoming years: Agora Energiewende (2015) estimates that the number of excess allowances could increase to 3.8 billion in 2020, before the MSR ensures a declining; surplus (Figure 4). In the end, it may take until 2030 that the surplus eventually ranges within the defined interval of 400 to 833 million allowances. As a consequence, according to Agora Energiewende (2015), a significant price increase is not expected before 2025. Therefore, Neuhoff et al. (2015) suggest an earlier introduction of the MSR already in 2017, as well as transferring the backloaded allowances to the MSR.

Figure 3: Functioning of the MSR

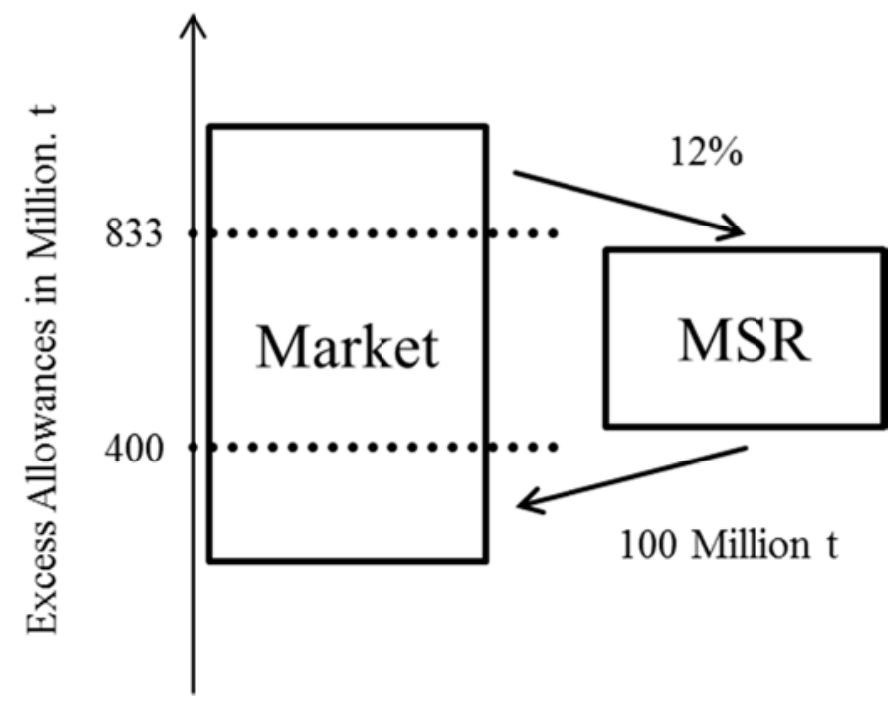

Source: DEHSt (2014:6)

Apart from the specific criticism of the long-standing temporal delay, there are more general doubts with respect to the effectiveness of the MSR. Koch et al. (2014:683), for instance, criticize that due to the moderate effect of demand shocks on the allowance price, the MSR is not suited to substantially push the price level. These authors, as well as Grubb and Newberry (2008), argue that supplementing the ETS by defining a price floor or a corridor for allowance prices would be more appropriate (Koch et al., 2014:684). To evaluate these measures, the subsequent section discusses the welfare effects of price- and quantity- 
based instruments, as well as combinations thereof, thereby accounting for the fact that, in reality, decisions have to be made under uncertainty.

Figure 4: Potential Evolution of Excess Allowances and the MSR according to the Proposal of the Commission

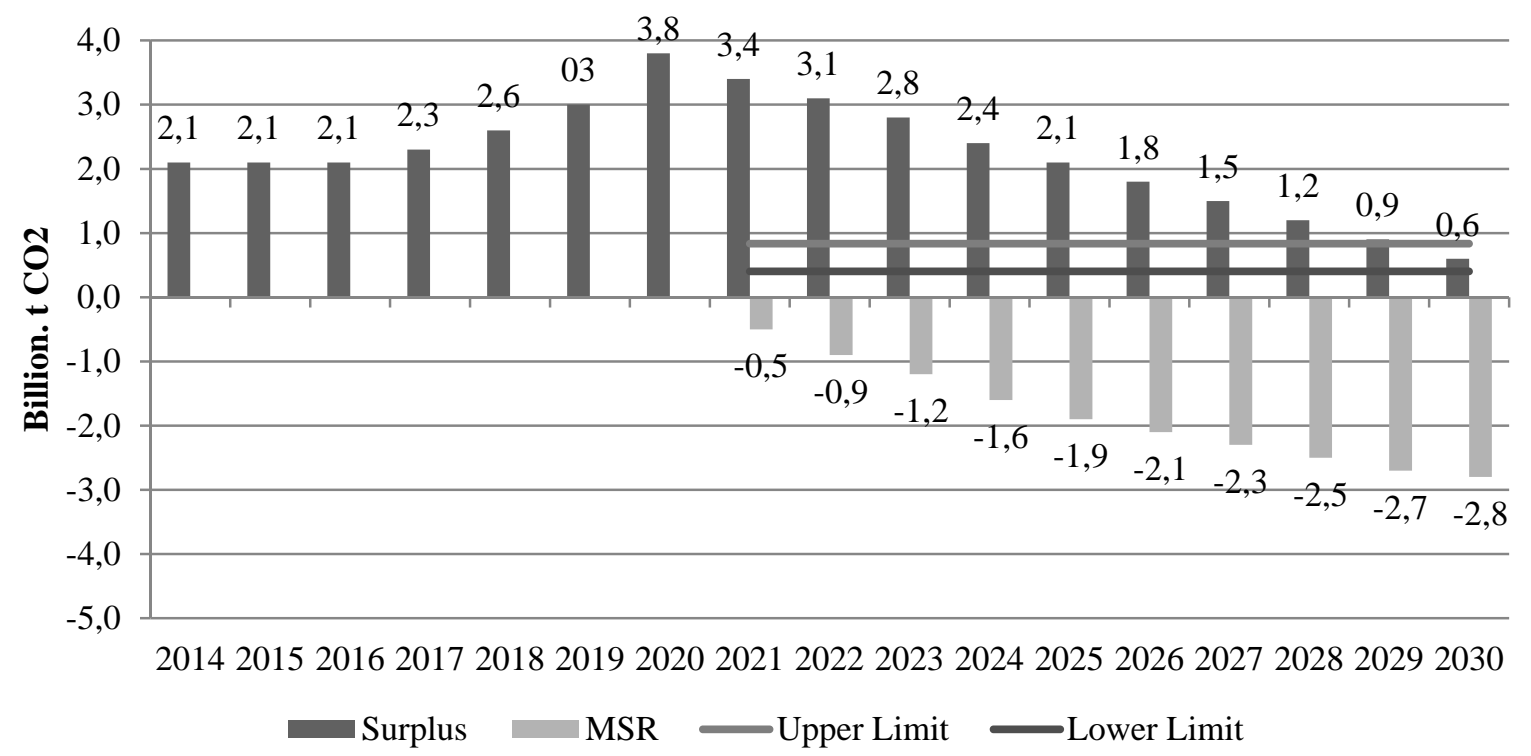

Source: Agora Energiewende (2015)

\section{Quantity- versus Price-Based Instruments}

The debate on whether emissions should be abated by either price-based interventions (e.g. taxes) or quantity-based instruments (e.g. trading schemes) has been going on for decades. Martin Weitzman (1974) formalized this discussion in his seminal paper "Prices vs. Quantities”. According to the so-called Weitzman-Theorem, under perfect information, price and quantity-based instruments yield the same optimum of emission abatement, regardless of whether the price or the quantity is fixed. Indeed, if the shapes of the marginal benefit curve $(M B)$ and marginal cost curve $\left(M C_{a}\right)$ were to be known, either the emissions cap $E^{*}$ or the tax rate $t^{*}$ could be set (Figure 5) and both alternatives would provide the same optimal pricequantity combination.

Yet, if the shapes of $M B$ and $M C_{a}$ are unknown - as it is the case in reality - priceand quantity-based instruments generally yield divergent outcomes. If emission caps and tax rates are set on the basis of expected marginal costs, $M C_{e}$, rather than the actual marginal cost curve, $M C_{a}$, the comparative advantage of either instrument, as well as the corresponding welfare losses, depend on the slopes of the curves at their intersection. This is the central insight of the Weitzman-Theorem. 
If both $M C_{a}$ exceeds $M C_{e}$ and its slope is larger than that of $M B$, the welfare loss $W_{q}$ resulting from the excessive cap $E_{q}$ is higher than the welfare loss due to the conservative tax rate $t: W_{q}>W_{t}$ (Figure 6a). In this case, the tax solution would be preferable. Conversely, if the slope of $M B$ is larger than that of $M C_{a}$, the implementation of a trading scheme will be preferable, as $W_{q}<W_{t}$ (Figure $6 \mathrm{~b}$ ). In both cases, the quantity-based solution would abate more emissions than it would be optimal: $E_{t}<E^{*}<E_{q}$. This result reverses if actual marginal abatement costs are lower than expected: $M C_{a}<M C_{e}$.

Figure 5: Illustration of the Weitzman-Theorem

a)

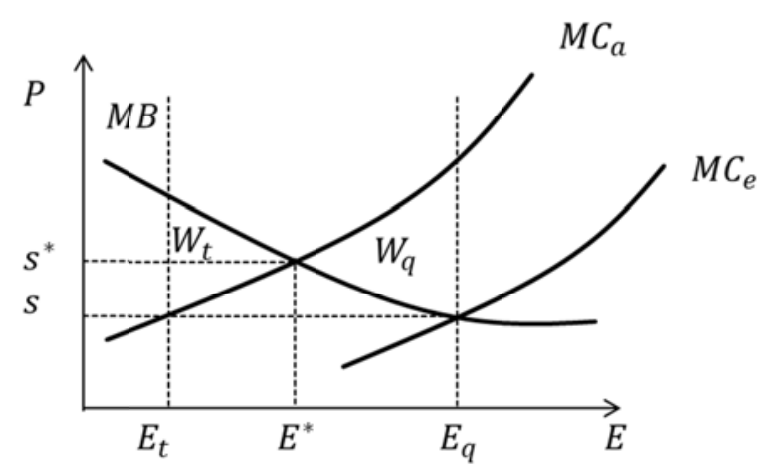

b)

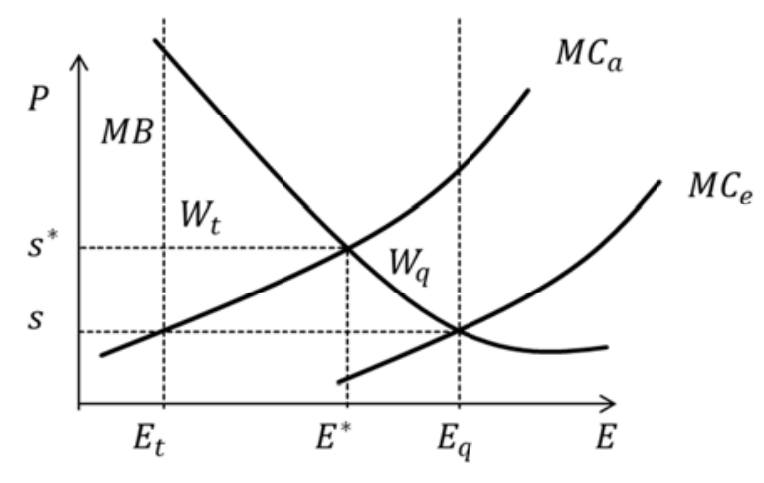

Source: Hepburn (2006:232)

Due to the uncertainty about the actual shapes of the marginal cost and marginal benefit curves, in the literature, there is a highly controversial debate on which instrument should be implemented in practice. Based on the argument that climate change is a gradual phenomenon and that damages depend on the stock of emissions, rather than the current emissions level, Pizer (2002) assumes a flat marginal benefit curve, because additional emissions would not lead to a stark increase of damages. ${ }^{6}$ In contrast, the marginal cost curve is assumed to be rather steep, as it seems plausible that it becomes more tedious to abate emissions after having picked the cheap and "low-hanging-fruits" (Hepburn, 2006:231). Recalling the discussion from above, in such a set-up, price-based solutions would be favorable. An additional advantage of a tax is that it would offer more planning security than quantitative controls, because a tax is less volatile (BMWi, 2012:13).

Moreover, Hoel and Karp (2002) argue that price-based solutions are more suited to achieve emission targets in the short term. In contrast, quantity regulation would be the preferable option in case of long-term climate protection agreements that guarantee emission

\footnotetext{
${ }^{6}$ In the case of reducing emissions the marginal benefit consists of avoiding the marginal damage caused by emissions.
} 
reductions over several decades. The reason for this claim is that limiting emissions would be particularly important if the world was to be close to a tipping point whose crossing increases the likelihood of a climatic catastrophe (Hepburn, 2006:232). Crossing the tipping point becomes more likely as the time horizon of the climate protection agreement increases (Hepburn, 2006:238).

The high degree of uncertainty with respect to the shapes of the marginal cost and benefit curves gives also rise to combining both price and quantity based approaches into socalled hybrid instruments, such as a trading system with a floor for certificate prices. Price floors would only prove effective in cases of low demand, as in such situations, the price floor prevents market prices from falling below a lower bound (Figure 6). Then, a price floor works like a tax whose rate equals the difference between the price floor and the hypothetical market price that would be observed in the absence of the price floor. In situations in which the price floor is binding, companies would invest in additional abatement measures, rather than purchasing more expensive allowances, leading to an excess supply ( $\left.C a p-E_{A}\right)$ of allowances (Figure 6).Then, an independent institution, e.g. a so-called European Allowance Bank, would have to buy the excess supply ( $\left.\operatorname{Cap}-E_{A}\right)$ to stabilize the trading scheme. In essence, a price floor thus causes a reduction of the emissions cap, something that could also be achieved by other measures, however, such as the permanent deletion of excess allowances.

Another hybrid instrument with which the uncertainty about allowance prices among market participants could be reduced is a price corridor (Koch et al., 2014:678). A key property of price corridors is the definition of a ceiling price, which becomes relevant in situations characterized by high demand and high scarcity (demand curve $D$ in Figure 7). In such situations, as the allowance price cannot exceed the ceiling price, companies would not invest in additional abatement measures when the ceiling price is reached, but instead would purchase allowances. Because the originally fixed supply cannot meet demand, more allowances must be made available, e.g. by a European Allowance Bank. As a consequence, the definition of a ceiling price in trading schemes is equivalent to raising the emissions cap. The tighter the price corridor in the trading scheme is defined, that is, the smaller the difference between the ceiling price and the price floor, the more it resembles a tax. Conversely, a trading scheme with a price corridor resembles a pure trading system if the corridor is broad, so that the allowance price can fluctuate almost freely. 
Figure 6: Effect of a Price Floor for Allowances in Trading Schemes

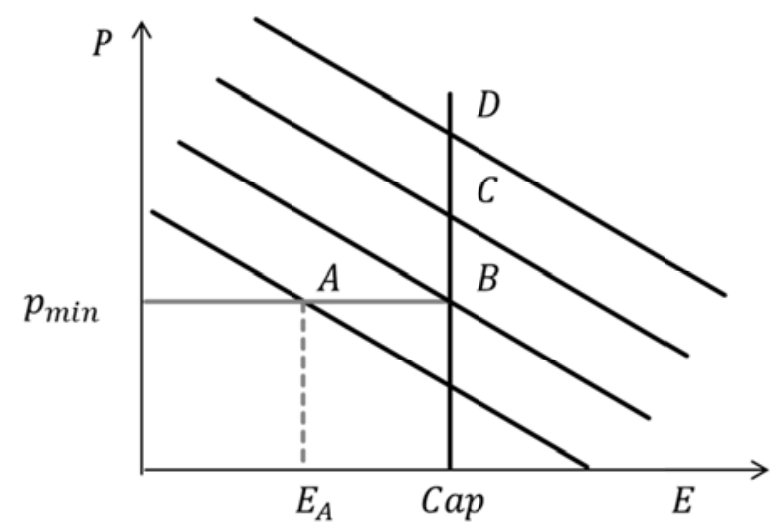

It has been demonstrated in the literature that, compared to pure instruments for emission abatement, hybrid instruments can lead to welfare gains (Roberts and Spence, 1976). For instance, in a simulation analysis, Pizer (2002) finds that a trading scheme with a trigger price, at which additional allowances are offered to the market, exhibits slightly better welfare effects than a pure tax system. Since empirical evidence on the shapes of the marginal cost and benefit curves is hardly available, this section's theoretical discussion does not provide ultimate guidance on the issue of which instrument may be more suited for emissions reduction. Hence, in the following, we discuss the potential consequences of these instruments in political practice.

A major advantage of retaining the pure trading system without price restrictions is its stabilizing effect on economic activity: While in growth and boom phases, high $\mathrm{CO}_{2}$ prices may dampen economic activity and help to avoid economic overheats, in times of economic crises, low allowance prices translate into low power prices and, thus, may relieve both companies and consumers. In fact, this can be seen as one of the virtues of the ETS: it is inherently cyclical, with low prices prevailing in economic busts when emissions are low and high prices in booms when emissions are high.

Figure 7: Effect of a Price Corridor in Trading Schemes

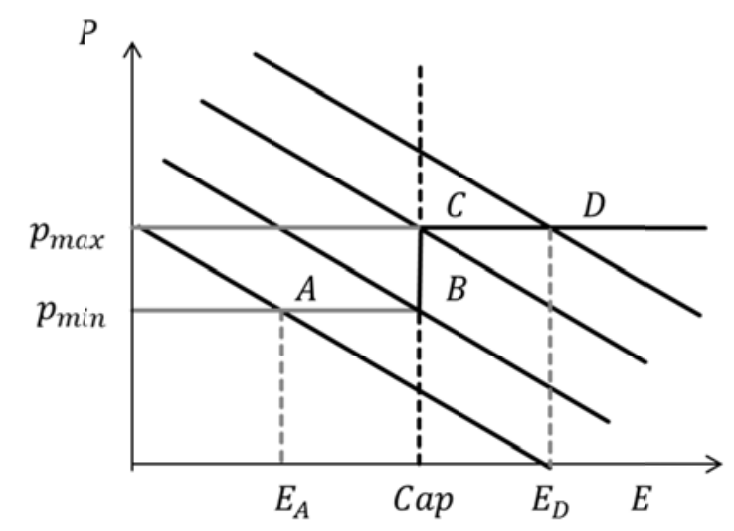


In contrast, a price floor has the disadvantage that it increases the cost burden for companies during recessive periods, while the ceiling of a price corridor limits the dampening effect of high allowance prices in boom cycles. Another disadvantage of a price floor is that this instrument can be abused by politicians in order to generate revenues. In fact, it is precisely the desire for higher revenues that could result in a steady increase of the price floor. This worry is all the more warranted, as the "appropriate” price for emissions is unknown and, hence, there is no natural upper limit for political interventions with respect to the price floor.

Similarly, the MSR may also be prone to political interventions that aim at raising its lower and upper limits to impact allowances prices and generate revenues. The resulting uncertainties from such discretionary interventions may negatively affect both the innovation behavior of firms and their GHG emission levels. In sum, as a general rule, it must be recognized that any intervention into the mechanism of the ETS entails uncertainties, most importantly about the future amount of allowances, which may have negative consequences for investments in emission abatement technologies.

\section{Summary and Conclusions}

Prices for emission allowances were notoriously low in recent years. This fact is frequently interpreted as a symptom of an insufficient functioning of the European Emissions Trading System (ETS) and used as a justification for the necessity of reforming it. This argument, however, is questionable, as a low allowance price is not a sign that the trading scheme works imperfectly (Keohane, Wagner, 2013). Rather, low prices may indicate that either the emissions cap has not been ambitiously enough (e.g. as the result of a sluggish economy) or that the abatement costs have turned out to be lower than expected.

Actually, both reasons apply to the past, so that at the end of 2013, the surplus allowances in the ETS amounted to more than 2.2 billion (Gibis et al., 2015:26). The vast majority of this surplus has been attributed to offsets from international climate projects (ÖkoInstitut, 2013). These offsets are supposed to enable companies to exploit cheap emission reduction potentials outside the European Union, thereby simultaneously facilitating technology transfer and stimulating economic growth abroad. Yet, as numerous dubious projects were supported in the past, since 2013, the amount of offsets was limited for each EU Member State to half of the emissions to be reduced between 2008 and 2020.

These measures, as well as postponing the auctioning of 900 million allowances from 2014-2016 to 2019 and 2020, however, did not lead to a reduction of the surplus and, hence, 
the rise in allowance prices was commensurately low. Therefore, the European Commission recently decided to introduce a market stability reserve (MSR), a rule-based mechanism to steering the market volume of allowances with which it is hoped to stabilize allowance prices at a substantially higher level than currently observed. From the Commission's MSR proposal, though, significant price increases cannot be expected in the short run, most notably due to the foreseen late introduction in 2019. In addition, there are more general doubts about the effectiveness of this instrument: Koch et al. (2014:683), for instance, criticize that the MSR is principally ineffective in establishing a politically desired price level because of the low impact of demand shocks on the allowance prices.

Based on our reflections in this article, we alternatively recommend retaining the trading scheme in its pure form, instead of supplementing it by a price floor or a MSR. Past mistakes, above all the generous issuing of offsets resulting from dubious international climate protection projects, should be corrected by a single intervention: deleting, rather than backloading, the 900 million allowances that are planned to be brought back to the market in 2019 and 2020. Irrevocably deleting this amount of allowances will certainly have stronger consequences than temporally storing them in a MSR. Moreover, if it is politically desired to further stabilize the price, the emissions cap could be reduced more strongly (Keohane, Wagner, 2013) than currently planned (2.2\% per year) as of 2021, the start of the fourth trading phase. 


\section{References}

acatech - Deutsche Akademie der Technikwissenschaften, Nationale Akademie der Wissenschaften Leopoldina, Union der deutschen Akademien der Wissenschaften (Hrsg.) (2015), Die Energiewende europäisch integrieren. Neue Gestaltungsmöglichkeiten für die gemeinsame Energie- und Klimapolitik. Schriftenreihe zur wissenschaftsbasierten Politikberatung, München 2015, i.E.

Agora Energiewende (2015), Die Rolle des Emissionshandels in der Energiewende. Perspektiven und Grenzen der aktuellen Reformvorschläge. Berlin.

Baumol, W., Oates, E. W. (1988), The Theory of Envioronmental Policy. Cambridge University Press, Cambridge.

BMU - Bundesministerium für Umwelt, Naturschutz und Reaktorsicherheit (2015), $\mathrm{CDM} / \mathrm{JI}$ und der Emissionshandel. Berlin. http://www.jikobmub.de/basisinformationen/einfuehrung_cdm_und_ji/cdm_ji_und_emissionshandel/doc/174. php

BMWA - Bundesministerium für Wirtschaft und Arbeit (2004), Zur Förderung Erneuerbarer Energien. Gutachten des Wissenschaftlichen Beirats beim Bundesministerium für Wirtschaft und Arbeit. BMWA-Dokumentation Nr. 534. Berlin.

BMWi - Bundesministerium für Wirtschaft und Technologie (2012), Wege zu einer wirksamen Klimapolitik. Gutachten des Wissenschaftlichen Beirats beim Bundesministerium für Wirtschaft und Technologie. Berlin.

Bonus, H. (1998), Umweltzertifikate. Der steinige Weg zur Marktwirtschaft. Zeitschrift für Angewandte Umweltforschung 10 (Sonderheft 9): 7-8.

DEHSt - Deutsche Emissionshandelsstelle (2014), Stärkung des Emissionshandels. Diskussionsbeitrag zur Ausgestaltung der Marktstabilitätsreserve (MSR). Berlin.

EEX - European Energy Exchange (2015), EUA Primary Auction Spot. Leipzig. http://www.eex.com/de/marktdaten/emissionsrechte/auktionsmarkt/european-emissionallowances-auction/european-emission-allowances-auction-download

EC - European Commission (2013), The EU Emissions Trading System. EU Factsheet. Brüssel.

EC - European Commission (2014a), Verordnung Nr. 176/2014 der Kommission zur Änderung der Verordnung (EU) Nr. 1031/2010 insbesondere zur Festlegung der im Zeitraum 2013-2020 zu versteigernden Mengen Treibhausgasemissionszertifikate. Brüssel.

EC - European Commission (2014b), Proposal for a Decision of the European Parliament and of the Council Concerning the Establishment and Operation of a Market StabilityReserve for the Union Greenhouse Gas Emission Trading Scheme and Amending Directive2003/87/EC. Brüssel. 
EC - European Commission (2015), Structural reform of the European carbon market. Brüssel. http://ec.europa.eu/clima/policies/ets/reform/index_en.htm

EP - Europäisches Parlament (2010), Amtsblatt der Europäischen Union. Rechtsvorschriften L 279. 53. Jahrgang, 23.10.2010. Brüssel.

ER - Europäischer Rat (2014), European Council Conclusions - 23 and 24 October 2014. EUCO 169/14. Brüssel.

Fell, H., Morgenstern, R. (2010), Alternative Approaches to Cost Containment in a Capand-Trade System. Environmental and Resource Economics 47(2): 275-297.

Frondel, M., S. Sommer, Vance, C. (2015), The Burden of Germany’s Energy Transition: An Empirical Analysis of Distributional Effects. Economic Analysis and Policy 45: 89-99.

Gibis, C., J. Weiß, Kühleis, C. (2015), Stärkung des europäischen Emissionshandels notwendig und greifbar. Ifo Schnelldienst 68(1): 26-31.

Grubb, M., Newberry, D. (2008), Pricing Carbon for Electricity Generation: National and International Dimensions. In Delivering a Low Carbon Electricity System

Technologies, Economics and Policy. Hrsg. Grubb, M., T. Jamasb und M. G. Pollit. Cambridge University Press.

Grüll, G., Taschini, L. (2011), Cap-and-trade properties under different hybrid scheme designs. Journal of Environmental Economics and Management 61: 107-118.

Hepburn, C. (2006), Regulation by Prices, Quantities or Both: A Review of Instrument Choice. Oxford Review of Economic Policy 22(2): 226-247.

Hoel, M., Karp, L. (2002), Taxes and quotas for a stock pollutant. Resource and Energy Economics 24: 367-384.

ICAP - International Carbon Action Partnership (2015), Status Report 2015. Berlin. https://icapcarbonaction.com

Keohane, N., Wagner, G. (2013), Judge a carbon market by its cap, not its prices. Financial Times, July 16, 2013.

Koch, N., S. Fuss, G. Grosjean, Edenhofer, O. (2014), Causes of the EU ETS price drop: Recession, CDM, renewable policies or a bit of everything?-New evidence. Energy Policy 73: 676-85.

Neuhoff, K., A. Schopp. (2013), Europäischer Emissionshandel: Durch Backloading Zeit für Strukturreform gewinnen. DIW Wochenbericht 11.2013: 3-11.

Neuhoff, K.,W. Acworth, R. Betz, D. Burtraw, J. Cludius, H. Fell, C. Hepburn, C. Holt, F. Jotzo, S. Kollenberg, F. Landis, S. Salant, A. Schopp, W. Shobe, L. Taschini, R. 
Trotignon (2015), Is a Market Stability Reserve likely to improve the functioning of the EU ETS? Evidence from a model comparison exercise. Climate Strategies, London.

Öko-Institut (2013), Europäisches Emissionshandelssystem - Bilanz und zukunftsfähige Ausgestaltung. Stellungnahme zur Anhörung des Ausschusses für Umwelt, Naturschutz und Reaktorsicherheit des 17. Deutschen Bundestages. Berlin, Freiburg, Darmstadt.

Pizer, W. A. (2002), Combining price and quantity controls to mitigate global climate change. Journal of Public Economics 85: 409-434.

Roberts, M. J., Spence, M. (1976), Effluent charges and licenses under uncertainty. Journal of Public Economics 5: 193-208.

SRU - Sachverständigenrat für Umweltfragen (2011), Wege zur 100\% erneuerbaren Stromversorgung. Sondergutachten. Berlin.

UNFCC - United Nations Framework on Climate Change (2015a), Clean Development Mechanism. Bonn. http://cdm.unfccc.int/index.html

UNFCC - United Nations Framework on Climate Change (2015b), Joint Implementation. Bonn. http://ji.unfccc.int/index.html

Weitzman, M. L. (1974), Prices vs. Quantities. The Review of Economic Studies 41(4): 477491.

Wood, P.J., Jotzo, F. (2011), Price Floor for Emissions Trading. Energy Policy 39: 17461753. 


